\title{
Surveillance of the rabies-related lyssavirus, Mokola in non-volant small mammals in South Africa
}

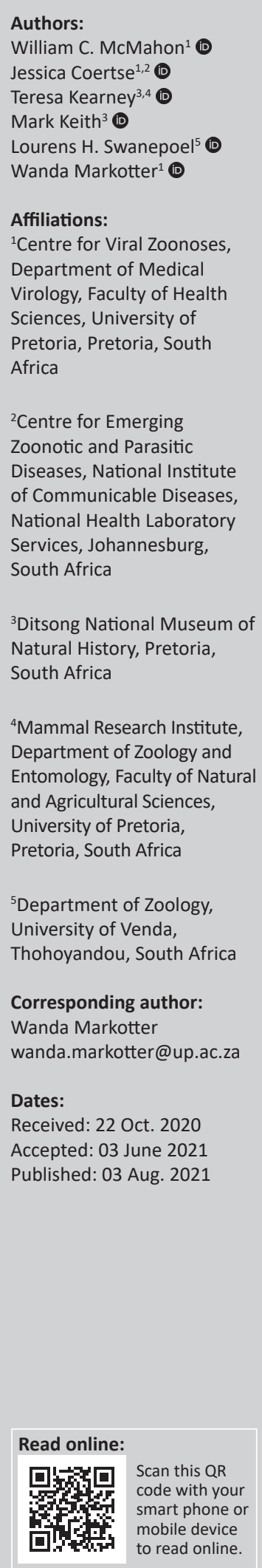

The reservoir host of Mokola virus (MOKV), a rabies-related lyssavirus species endemic to Africa, remains unknown. Only sporadic cases of MOKV have been reported since its first discovery in the late 1960s, which subsequently gave rise to various reservoir host hypotheses. One particular hypothesis focusing on non-volant small mammals (e.g. shrews, sengis and rodents) is buttressed by previous MOKV isolations from shrews (Crocidura sp.) and a single rodent (Lophuromys sikapusi). Although these cases were only once-off detections, it provided evidence of the first known lyssavirus species has an association with non-volant small mammals. To investigate further, retrospective surveillance was conducted in 575 small mammals collected from South Africa. Nucleic acid surveillance using a pan-lyssavirus quantitative real-time reverse transcription polymerase chain reaction (qRT-PCR) assay of 329 brain samples did not detect any lyssavirus ribonucleic acid (RNA). Serological surveillance using a micro-neutralisation test of 246 serum samples identified 36 serum samples that were positive for the presence of MOKV neutralising antibodies (VNAs). These serum samples were all collected from Gerbilliscus leucogaster (Bushveld gerbils) rodents from Meletse in Limpopo province (South Africa). Mokola virus infections in Limpopo province have never been reported before, and the high MOKV seropositivity of $87.80 \%$ in these gerbils may indicate a potential rodent reservoir.

Keywords: Bushveld gerbil; lyssavirus; Mokola; non-volant small mammal; rabies-related; reservoir; rodent; surveillance.

The Mokola virus (MOKV), a rabies-related lyssavirus, represents one of 17 recognised species within the Lyssavirus genus, all capable of causing a fatal encephalitic disease (Walker et al. 2018). The Mokola virus is exclusively endemic in Africa with only 30 sporadic cases reported since its discovery more than 50 years ago (Figure 1; Table 1) (Coertse et al. 2017; Kgaladi et al. 2013). The reservoir host of MOKV is still unknown, with spillover dead-end hosts such as domestic cats (Felis catus) and dogs (Canis familiaris), most commonly reported to be infected with MOKV. This has led to the hypothesis that the reservoir of MOKV might be a prey species that interacts with domesticated animals via a prey-to-predator pathway (Kgaladi et al. 2013). Non-volant small mammals (i.e. shrews, sengis and rodents) have been suggested as possible reservoir hosts considering that previous MOKV isolations were in shrews (Crocidura spp.), four in Nigeria and one in Cameroon (Causey et al. 1969; Kemp et al. 1972; Le Gonidec et al. 1978), and a single reported case in a rodent (Lophuromys sikapusi) in the Central African Republic (Saluzzo et al. 1984). To investigate further, nucleic acid and serological surveillance were retrospectively conducted, targeting non-volant small mammals from specific locations in South Africa.

Non-volant small mammals were captured and sampled in accordance with the field procedure guidelines of Sikes and Gannon (2011) during the period of 2015-2017 from two different sites in South Africa: Meletse area in Limpopo province $\left(24.5914^{\circ} \mathrm{S}, 27.6258^{\circ} \mathrm{E}\right)$ and Secunda area in Mpumalanga Province (26.5158 S, $\left.29.1914^{\circ} \mathrm{E}\right)$. All the species investigated were designated as of Least Concern by The International Union for Conservation of Nature Red List of Threatened Species. Morphological species identification followed classifications by Meester et al. (1986), Newbery (1999), as well as Monadjem et al. (2015). Following morphological identification, animals were anesthetised with Isofor (Safeline Pharmaceuticals, South Africa), after which blood was collected by cardiac puncture $(1 \%-3 \%$ volume/body mass) in $0.8 \mathrm{~mL}$ MiniCollect serum separator tubes (Greiner Bio-One, Austria). Serum was separated from whole blood by centrifugation (Centrifuge 5418, Eppendorf, Germany) at $4300 \mathrm{~g}$ for $5 \mathrm{~min}$ and transferred to $2.0 \mathrm{~mL}$ Sarstedt tubes (Sarstedt Inc.). Animals that were not collected as voucher specimens were

How to cite this article: McMahon, W.C., Coertse, J., Kearney, T., Keith, M., Swanepoel, L.H. \& Markotter, W., 2021, 'Surveillance of the rabies-related lyssavirus, Mokola in non-volant small mammals in South Africa', Onderstepoort Journal of Veterinary Research 88(1), a1911. https://doi.org/10.4102/ojvr.v88i1.1911

Copyright: (C 2021. The Authors. Licensee: AOSIS. This work is licensed under the Creative Commons Attribution License. 


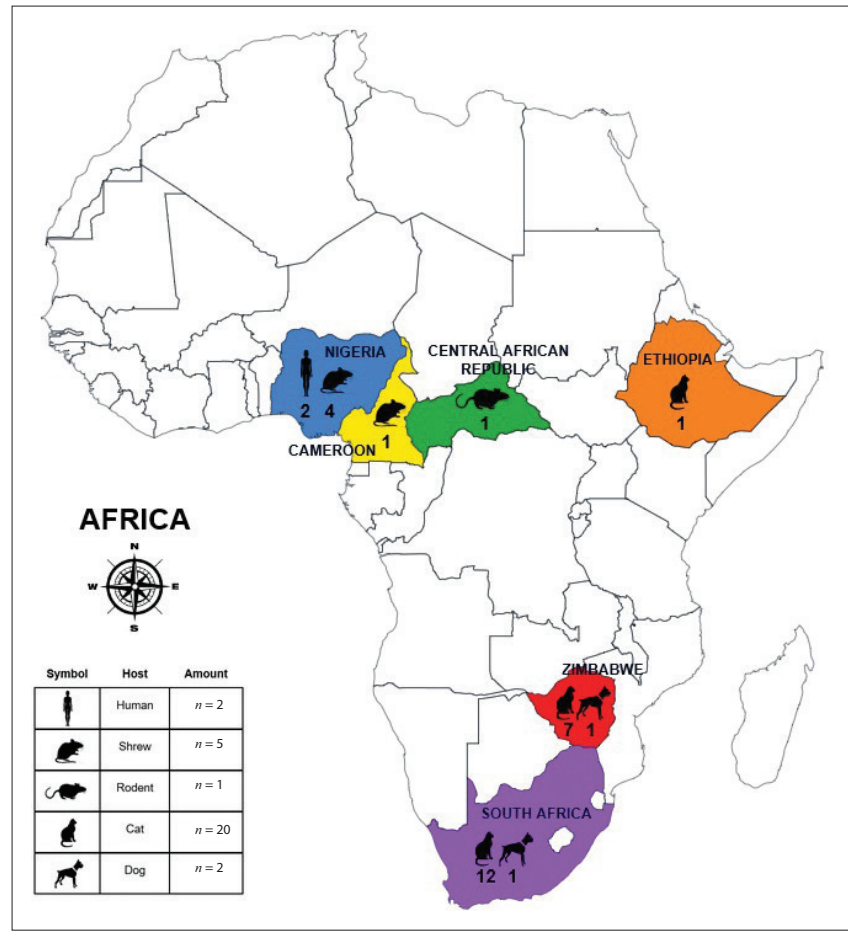

Nigeria (blue) with a total of six MOKV cases, four from shrews (Crocidura sp.) and two from humans (Homo sapiens). Cameroon (yellow) with a single MOKV case in a shrew (Crocidura $s p$.). The Central African Republic (green) with a single MOKV case in a rodent (Lophuromys sikapusi). Ethiopia (orange) with a single MOKV case in a cat (Felis catus). Zimbabwe (red) with a total of eight MOKV cases, one from a dog (Canis familiaris) and seven from cats (Felis catus). South Africa (purple) with a total of 13 MOKV cases, one from a dog (Canis familiaris) and 12 from cats (Felis catus).

FIGURE 1: Geographical distribution of all reported Mokola virus cases $(n=30)$ in the African continent. marked with a unique tattoo number near the base of their tail, and released back to their respective capture sites. Voucher specimens were euthanised with an overdose of Isofor, after which their organs were harvested (i.e. brain, tongue, salivary glands, heart, kidney, lungs, pectoral muscle, spleen, intestines, rectum and bladder) in $2.0 \mathrm{~mL}$ Sarstedt tubes for a broader pathogen surveillance study and immediately stored in liquid nitrogen until storage at $-80^{\circ} \mathrm{C}$. Carcasses were placed in a $3 \mathrm{~L}$ PathoPak (Intelsius Solutions, United Kingdom [UK]) containing 80\% ethanol and were submitted to Ditsong National Museum of Natural History and the Natural History Collection for Public Health and Economics for voucher-based morphological identification, and museum archiving.

Total ribonucleic acids (RNAs) were extracted from brain samples $(n=329)$ (nine shrews, four sengis and 316 rodents) using TRIzol ${ }^{\mathrm{TM}}$ reagent (Invitrogen, United States [US]), followed by nucleic acid surveillance using a pan-lyssavirus quantitative real-time reverse transcription polymerase chain reaction (qRT-PCR) assay as previously described (Coertse et al. 2019). Serum samples $(n=246)$ (three shrews, four sengis and 239 rodents) were subjected to serological surveillance using a micro-neutralisation test as previously described (Smith \& Gilbert 2017), during which MOKV 12/458 (2012, Felis catus, Durban, KwaZulu-Natal, South Africa) (Coertse et al. 2017) was used as challenge virus. If a reduction or absence of fluorescence was observed at the 1:25 serum dilution during initial screening, the serum sample

TABLE 1: Summary of all reported Mokola virus cases in Africa.

\begin{tabular}{|c|c|c|c|c|c|}
\hline Date & $\begin{array}{l}\text { Virus/Laboratory } \\
\text { Reference Numbers }\end{array}$ & Host Species & Detection Material & Geographical Location & Reference $^{\ddagger}$ \\
\hline \multicolumn{6}{|l|}{ Nigeria $(n=6)$} \\
\hline May 1968 & IbAn $26801 \dagger$ & Crocidura sp. (Shrew) & $\begin{array}{l}\text { Organ pool (heart, lung, liver, } \\
\text { spleen \& kidney) }\end{array}$ & Ife Farm, Ibadan, Nigeria & $\begin{array}{l}\text { Causey and Kemp (1968); } \\
\text { Kemp et al. (1972) }\end{array}$ \\
\hline May 1968 & IbAn $27157 \dagger$ & Crocidura sp. (Shrew) & $\begin{array}{l}\text { Organ pool (heart, lung, liver, } \\
\text { spleen \& kidney) }\end{array}$ & $\begin{array}{l}\text { Private residence, University } \\
\text { of Ibadan, Ibadan, Nigeria }\end{array}$ & $\begin{array}{l}\text { Causey and Kemp (1968); } \\
\text { Kemp et al. (1972) }\end{array}$ \\
\hline July 1968 & $\begin{array}{l}\text { IbAn } 27377 \dagger \\
\text { RV4 }\end{array}$ & Crocidura sp. (Shrew) & $\begin{array}{l}\text { Organ pool (heart, lung, liver, } \\
\text { spleen \& kidney) }\end{array}$ & Mokola, Ibadan, Nigeria & $\begin{array}{l}\text { Causey and Kemp (1968); } \\
\text { Kemp et al. (1972) }\end{array}$ \\
\hline December 1969 & IbAn $51715 \dagger$ & Crocidura sp. (Shrew) & Organ pool (liver \& spleen) & $\begin{array}{l}\text { Virus Research Laboratory, } \\
\text { Ibadan, Nigeria }\end{array}$ & $\begin{array}{l}\text { Causeyand Kemp (1969); Kemp } \\
\text { et al. (1972) }\end{array}$ \\
\hline March 1971 & IbAn 56909† & Homo sapiens (Human) & Brain & Idikan, Ibadan, Nigeria & $\begin{array}{l}\text { Familusi and Moore (1972); } \\
\text { Kemp et al. (1972) }\end{array}$ \\
\hline \multicolumn{6}{|l|}{ Cameroon $(n=1)$} \\
\hline January 1974 & $\begin{array}{l}\text { An Y1307† } \\
\text { RV39 } \\
\text { 86100CAM }\end{array}$ & Crocidura sp. (Shrew) & Organ pool (brain, liver \& spleen) & $\begin{array}{l}\text { Nkol-Owona, Yaounde, } \\
\text { Cameroon }\end{array}$ & Le Gonidec et al. (1978) \\
\hline October 1981 & $\begin{array}{l}\text { AnRB3247 } \dagger \\
\text { RV40 } \\
86101 \text { RCA }\end{array}$ & $\begin{array}{l}\text { Lophuromys sikapusi } \\
\text { (Rodent) }\end{array}$ & Brain & $\begin{array}{l}\text { Botami, Bangui, Central African } \\
\text { Republic }\end{array}$ & Saluzzo et al. (1984) \\
\hline \multicolumn{6}{|l|}{ Ethiopia $(n=1)$} \\
\hline 1989-1990 & $\begin{array}{l}\text { Eth-16 } \\
\text { RA } 133 / 82 \\
\text { RV610 }\end{array}$ & Felis catus (Cat) & Brain & Addis Ababa, Ethiopia & $\begin{array}{l}\text { Mebatsion, Cox and Frost } \\
\text { (1992) }\end{array}$ \\
\hline \multicolumn{6}{|l|}{ Zimbabwe $(n=8)$} \\
\hline April 1981 & $12017 \dagger$ & Felis catus (Cat) & Brain & Bulawayo, Zimbabwe & Foggin (1982); Foggin (1988) \\
\hline May 1981 & $12245 \dagger$ & Felis catus (Cat) & Brain & Bulawayo, Zimbabwe & Foggin (1982); Foggin (1988) \\
\hline June 1981 & $12341 \dagger$ & Felis catus (Cat) & Brain & Bulawayo, Zimbabwe & Foggin (1982); Foggin (1988) \\
\hline August 1981 & $12574 \dagger$ & Felis catus (Cat) & Brain & Bulawayo, Zimbabwe & Foggin (1982); Foggin (1988) \\
\hline October 1981 & $12800 \dagger$ & Canis familiaris (Dog) & Brain & Bulawayo, Zimbabwe & Foggin (1982); Foggin (1988) \\
\hline March 1982 & $13270 \dagger$ & Felis catus (Cat) & Brain & Bulawayo, Zimbabwe & Foggin (1983); Foggin (1988) \\
\hline
\end{tabular}


TABLE 1 (Continues...): Summary of all reported Mokola virus cases in Africa.

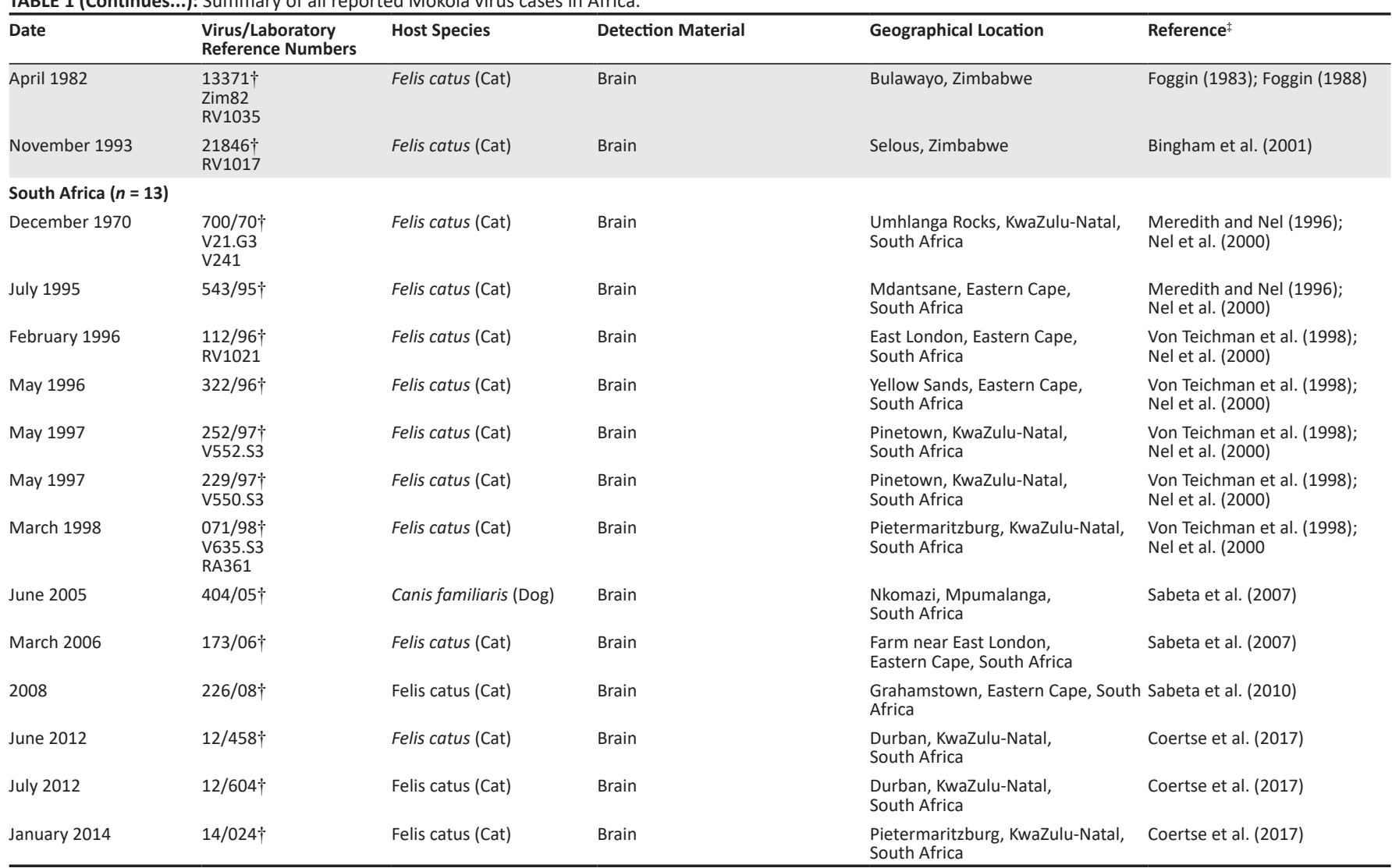

Sp., species; RV, rabies virus; IbAn, Ibadan.

$\dagger$, The original virus reference number as indicated in the reference article(s); $\$$, References form part of Appendix 2 .

was subjected to follow-up screening (in duplicate) at 1:10, 1:50, 1:250 and 1:1250 serum dilutions. The 50\% end-point (ED) neutralisation titre was calculated by the Reed and Muench method (1938) and considered positive for Mokola virus neutralising antibodies (MOKV VNAs) when they had a $50 \%$ ED neutralisation titre at a serum dilution of $\geq 25$ (i.e. where $\leq 5$ out of the 10 counted fields contain infected cells at the 1:25 serum dilution). If additional material was available, non-volant small mammals that tested positive for the presence of MOKV VNAs were subjected to genetic species identification with the Cytochrome B (CytB) barcoding PCR assay as previously described (Greenberg et al. 2012). Template deoxyribonucleic acid (DNA) required for the barcoding assay was extracted from various biological sample types (such as blood, kidney, heart and pectoral tissue) using the Quick-DNA ${ }^{\mathrm{TM}}$ Miniprep Plus Kit (Zymo Research, US).

All of the brain samples were negative for the presence of viral RNA with the pan-lyssavirus qRT-PCR assay (Appendix Table 1-A1). Negative results were expected as these animals were apparently healthy individuals and did not exhibit any visible signs of disease. An overall MOKV seropositivity of $87.80 \%$ (36 out of 41 ) was observed for the gerbils (Gerbilliscus leucogaster) tested from Meletse at the cut-off 1:25 serum dilution (Figure 2; Appendix Tables 1-A1, 2-A1, 3-A1 \& 4-A1). The titre ranges for this rodent species were high when compared to another serological surveillance study

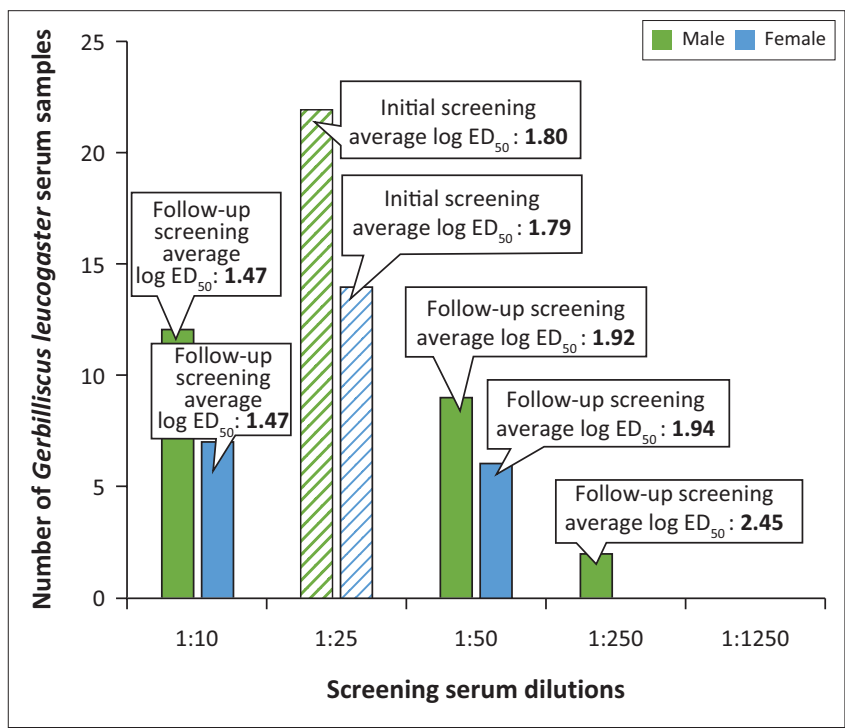

$\mathrm{ED}_{50}$, effective dose.

A total of 36 gerbils neutralised MOKV infection at 1:25 serum dilution during initial screening. Follow-up screening of the 36 gerbils that were positive for the presence of MOKV VNAs at the 1:25 serum dilution, identified 19 gerbils that neutralised MOKV infection until the 1:10 serum dilution, whereas 15 neutralised until the 1:50 serum dilution. Only two the $1: 10$ serum dilution, whereas 15 neutralised until the 1:50 serum dilution. Only two
gerbils neutralised MOKV infection until the 1:250 serum dilution, whereas none of the gerbils neutralised MOKV infection until the 1:250 serum dilution, whereas none of the
gerbils neutralised MOKV infection until the 1:1250 serum dilution. The timing of sampling gerbils neutralised MOKV infection
events is indicated in Table 2-A1.

FIGURE 2: Graphical representation of the micro-neutralisation test results of the Gerbilliscus leucogaster serum samples from Meletse $(n=36)$.

conducted in Zimbabwe (Foggin 1988). Foggin identified MOKV VNAs in 5.63\% (18 out of 320) of all rodents that were tested. An overall MOKV seropositivity of $17.57 \%$ 


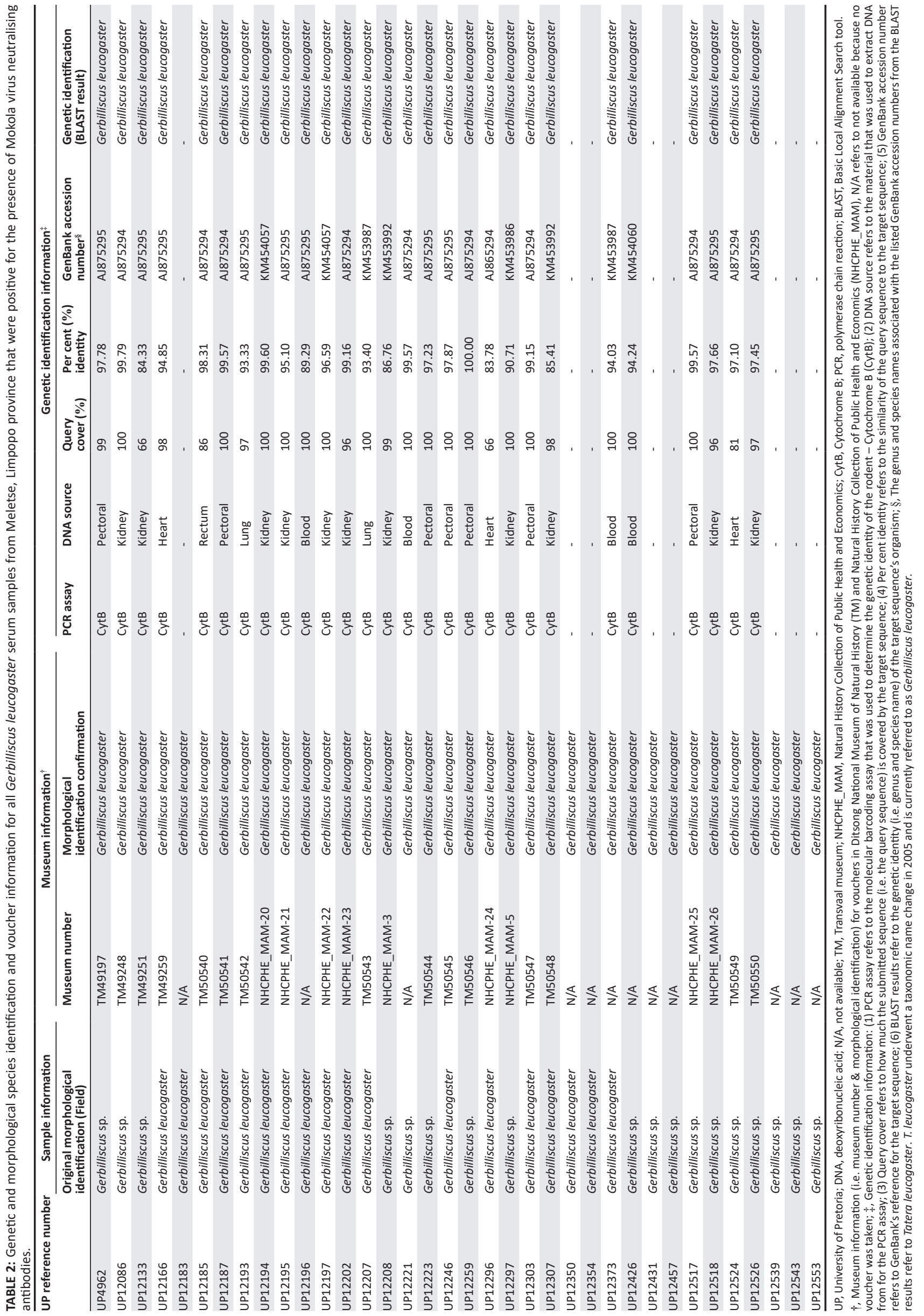


(13 out of 74) was observed for gerbils which neutralised MOKV infection at various serum dilutions that ranged from $1: 8,1: 16$ to $1: 32$. None of the other MOKV serological surveillance studies have tested this rodent species for the presence of MOKV VNAs (Aghomo et al. 1990; Kemp et al. 1972; Nottidge, Omobowale \& Oladiran 2007; Ogunkoya et al. 1990). Even though MOKV has been shown to cross-react in serological assays with other closely-related lyssaviruses (Kuzmin et al. 2008), cross-reactivity with other phylogroup II lyssaviruses was not investigated in this study.

Of the 36 gerbils showing MOKV seropositivity, only 28 were genetically identified with the CytB barcoding PCR assay (Table 2). The same identification was obtained from morphological examination of 24 voucher specimens (Table 2). Eight gerbils could not be identified to species level as they were released and no additional sample material was available. The Highveld gerbil, Gerbilliscus brantsii, is sympatric with G. leucogaster, however, based on known museum records, no G. brantsii has been caught at Meletse before (Rautenbach 1982) and these were, therefore, allocated to G. cf. leucogaster. The variability observed in the per cent identity (i.e. $83.78 \%-100.00 \%$ ) between the individual gerbils is expected since previous molecular characterisation assays performed on the Gerbilliscus genus have recorded intraspecies genetic variation that range from $1 \%$ to $20 \%$ (Aghová et al. 2017; Colangelo et al. 2007).

Members of the Gerbilliscus genus are nocturnal and terrestrial, exhibit no sexual dimorphism (Skinner \& Chimimba 2005) and occupy simple to complex, deep burrows (i.e. warrens) (De Graaff 1981; Granjon \& Dempster 2013). They are physiologically, morphologically and behaviourally adapted to live in arid climates (Granjon \& Dempster 2013; Monadjem et al. 2015). Gerbilliscus leucogaster, however, is less arid adapted and can be found along rivers and drainage lines in open grasslands and wooded savannas (Dempster 2013; Monadjem et al. 2015). The breeding pattern and social organisation of G. leucogaster rodents are not well-understood, however, studies have reported a communal nature (De Graaff 1981; Smithers 1971) with burrows being occupied by a pair (Skinner \& Chimimba 2005) and some warrens housing families or several adults (Choate 1972). The ecological nature of Bushveld gerbils may potentially be the reason why this specific rodent species are more likely to be MOKV seropositive compared to solitary rodent species belonging to the Steatomys and Rhabdomys genera occurring at Meletse.

More nucleic acid and serological surveillance studies in non-volant small mammal populations are required to obtain a better understanding of MOKV distribution, prevalence and its potential reservoir species. Brain and serum samples in this study were collected from seemingly healthy small mammals in areas that do not coincide with areas where previous MOKV cases have been reported in South Africa. Surveillance should be expanded to areas where MOKV spillover infections in cats and dogs have previously been reported. Furthermore, because lyssavirus distribution and dynamics might be influenced by seasonality, surveillance efforts should also include samples that were collected in different seasons and over multiple years. This expansion, together with representative sample sizes of certain nonvolant small mammal species, will collectively increase the possibility of identifying more of these animals that are infected or that have previously been exposed to MOKV.

\section{Acknowledgements Competing interests}

The authors declare that they have no financial or personal relationships that may have inappropriately influenced them in writing this article.

\section{Authors' contributions}

W.C.M. performed all experiments associated with this study which forms part of his M.Sc. Medical Virology degree. J.C. and W.M. provided academic guidance and supervised the overall process and operations of this study. T.K., M.K. and L.H.S. assisted with non-volant small mammal sample collection and species identification in the field. T.K. provided museum information from the Ditsong National Museum of Natural History. All authors contributed equally to the construction of this research communication.

\section{Ethical considerations}

This study formed part of a larger surveillance programme of the Bio-surveillance and Ecology of Emerging Zoonoses Research Group in the Centre for Viral Zoonoses that focuses on zoonotic pathogens in bats and non-volant small mammals. The overall research had animal ethical clearance from the University of Pretoria's Animal Ethics Committee (AEC) (principal investigator: W.M.; project reference number: EC071-15) and had permission to do research in terms of Section 20 of the Animal Diseases Act of 1984 (Act No. 35 of 1984) from the Department of Agriculture, Land Reform and Rural Development (DALRRD) (Project Name: Epidemiology of zoonotic pathogens in rodents, shrews and sengis in Southern Africa; project reference number: 12/11/1/1/8). Sampling permits were obtained from Limpopo's Department of Economic Development, Environment and Tourism (ZA/ LP/73972 [2016-2017] and ZA/LP/83642 [2017-2018]) and Mpumalanga's Tourism and Parks Agency (MPB.5583 [2017]). The M.Sc. Committee from the University of Pretoria's School of Medicine, Faculty of Health Sciences approved the protocol of this research project (Project Reference Number: 13057368). Individual animal ethical clearance (Principal Investigator: WM.; Project Reference Number: H008-18), as well as research ethical clearance was obtained from the University of Pretoria's AEC and Research Ethics Committee (Project Reference Number: 426/2018).

\section{Funding information}

This study was funded by the South African Research Chair in Infectious Diseases of Animal (Zoonoses) from the 
National Research Foundation of the Department of Science and Innovation, W.M. (UID98339), as well as additional grants awarded to W.M. by the NRF (UID92524, UID85756 and UID91496). The National Research Foundation for funding the equipment based at the DNA Sanger Sequencing Facility in the Faculty of Natural of Agricultural Sciences, University of Pretoria (UID78566) and the Poliomyelitis Research Foundation.

\section{Data availability}

The authors confirm that the data supporting the findings of this study are available within the article and its supplementary materials.

\section{Disclaimer}

The contents of this research communication are solely the responsibility of the authors. The opinions, findings and conclusions expressed do not necessarily reflect the official view of the National Research Foundation.

\section{References}

Aghomo, H.O., Tomori, O., Oduye, O.O. \& Rupprecht, C.E., 1990, 'Detection of Mokola virus neutralising antibodies in Nigerian dogs', Research in Veterinary Science 48(2), 264. https://doi.org/10.1016/S0034-5288(18)31005-1

Aghová, T., Šumbera, R., Piálek, L., Mikula, O., McDonough, M.M., Lavrenchenko, L.A et al., 2017, 'Multilocus phylogeny of East African gerbils (Rodentia, Gerbilliscus) illuminates the history of the Somali-Masai savanna', Journal of Biogeography 44(10), 2295-2307. https://doi.org/10.1111/jbi.13017

Causey, O.R., Kemp, G.E., Madbouly, M.H. \& Lee, V.H., 1969, 'Arbovirus surveillance in Nigeria, 1964-1967', Bulletin de la Société de Pathologie Exotique 62(2), 249-253.

Choate, T.S., 1972, 'Behavioural studies on some Rhodesian rodents', African Zoology 7(1), 103-118. https://doi.org/10.1080/00445096.1972.11447433

Coertse, J., Markotter, W., Le Roux, K., Stewart, D., Sabeta, C.T. \& Nel, L.H., 2017, 'New isolations of the rabies-related Mokola virus from South Africa', BMC Veterinary Research 13(1), 37. https://doi.org/10.1186/s12917-017-0948-0

Coertse, J., Weyer, J., Nel, L.H. \& Markotter, W., 2019, 'Reverse transcription recombinase polymerase amplification assay for rapid detection of canine associated rabies virus in Africa', PLoS One 14(7), e0219292. https://doi. org/10.1371/journal.pone.0219292

Colangelo, P., Granjon, L., Taylor, P.J. \& Corti, M., 2007, 'Evolutionary systematics in African gerbilline rodents of the genus Gerbilliscus: Inference from mitochondrial genes', Molecular Phylogenetics and Evolution 42(3), 797-806. https://doi. org/10.1016/j.ympev.2006.10.001

De Graaff, G., 1981, The rodents of southern Africa: Notes on their identification distribution, ecology, and taxonomy, Butterworth-Heinemann, Oxford, United Kingdom.

Dempster, E.R., 2013, 'Gerbilliscus leucogaster', Mammals of Africa 3, 279-281.
Foggin, C.M., 1988, 'Rabies and rabies-related viruses in Zimbabwe: Historical, virological and ecological aspects', PhD thesis, University of Zimbabwe, Harare.

Granjon, L. \& Dempster, E.R., 2013, 'Genus Gerbilliscus gerbils', Mammals of Africa 3, 268-270.

Greenberg, J.A., DiMenna, M.A., Hanelt, B. \& Hofkin, B.V., 2012, 'Analysis of postblood meal flight distances in mosquitoes utilizing zoo animal blood meals', Journal of Vector Ecology 37(1), 83-89. https://doi.org/10.1111/j.19487134.2012.00203.x

Kemp, G.E., Causey, O.R., Moore, D.L., Odelola, A. \& Fabiyi, A., 1972, 'Mokola virus' The American Journal of Tropical Medicine and Hygiene 21(3), 356-359. https:// doi.org/10.4269/ajtmh.1972.21.356

Kgaladi, J., Wright, N., Coertse, J., Markotter, W., Marston, D., Fooks, A.R. et al., 2013, 'Diversity and epidemiology of Mokola virus', PLOS Neglected Tropical Diseases 7(10), e2511. https://doi.org/10.1371/journal.pntd.0002511

Kuzmin, I.V., Niezgoda, M., Franka, R., Agwanda, B., Markotter, W., Beagley, J.C. et al., 2008, 'Lagos bat virus in Kenya', Journal of Clinical Microbiology 46(4), 1451-1461. https://doi.org/10.1128/JCM.00016-08

Le Gonidec, G., Rickenbach, A., Robin, Y. \& Heme, G., 1978, 'Isolement d'une souche de virus Mokola au Cameroun', Annales des Microbiologie (Institute Pasteur) 129(A), 245-249.

Meester, J.A.J., Rautenbach, I.L., Dippenaar, N.J. \& Baker, C.M., 1986, 'Classification of Southern African mammals', Transvaal Museum Monograph 5(1), 1-359.

Monadjem, A., Taylor, P.J., Denys, C. \& Cotterill, F.P., 2015, Rodents of sub-Saharan Africa: A biogeographic and taxonomic synthesis, Walter de Gruyter $\mathrm{GmbH} \&$ Co. KG, Berlin, Germany

Newbery, C.H., 1999, 'A key to the Soricidae, Macroscelididae, Gliridae and Muridae of Gauteng, North West Province, Mpumalanga and the Northern province, South Africa', Koedoe 42(1), 51-55. https://doi.org/10.4102/koedoe.v42i1.221

Nottidge, H.O., Omobowale, T.O. \& Oladiran, O.O., 2007, 'Mokola virus antibodies in humans, dogs, cats, cattle, sheep, and goats in Nigeria', International Journal of Applied Research in Veterinary Medicine 5(3), 105.

Ogunkoya, A.B., Beran, G.W., Umoh, J.U., Gomwalk, N.E. \& Abdulkadir, I.A., 1990 'Serological evidence of infection of dogs and man in Nigeria by lyssaviruses (family Rhabdoviridae)' Transactions of the Royal Society of Tropical Medicine and Hygiene 84(6), 842-845. https://doi.org/10.1016/0035-9203(90)90103-L

Rautenbach, I.L., 1982, Mammals of the Transvaal, Ecoplan monograph no. 1:1-211, Transvaal Museum, Pretoria.

Reed, L.J. \& Muench, H., 1938, 'A simple method of estimating fifty per cent endpoints', American Journal of Epidemiology 27(3), 493-497. https://doi.org/10.1093/ oxfordjournals.aje.a118408

Saluzzo, J.F., Rollin, P.E., Dauguet, C., Digoutte, J.P., Georges, A.J. \& Sureau, P., 1984 'Premier isolement du virus Mokola à partir d'un rongeur (Lophuromys sikapusi)' Annales de l'Institut Pasteur/Virologie 135(1), 57-66. https://doi.org/10.1016/ S0769-2617(84)80039-8

Sikes, R.S. \& Gannon, W.L., 2011, 'Guidelines of the American society of mammalogists for the use of wild mammals in research', Journal of Mammalogy 92(1), 235-253. https://doi.org/10.1644/10-MAMM-F-355.1

Skinner, J.D. \& Chimimba, C.T., 2005, The mammals of the Southern African subregion, Cambridge University Press, United Kingdom.

Smithers, R.H.N., 1971, A checklist of the mammals of Botswana, Trustees of the National Museum of Rhodesia, Salisbury.

Smith, T.G. \& Gilbert, A.T., 2017, 'Comparison of a micro-neutralization test with the rapid fluorescent focus inhibition test for measuring rabies virus neutralizing antibodies', Tropical Medicine and Infectious Disease 2(3), 24. https://doi. org/10.3390/tropicalmed2030024

Walker, P.J., Breyta, R., Blasdell, K.R., Calisher, C.H., Dietzgen, R.G., Fooks, A.R. et al., 2018, 'Rhabdoviridaee', in J.H. Kuhn \& S.G. Siddel (eds.), ICTV Report Negativesense RNA viruses, Journal of General Virology, 99, 447-448. viewed 24 May 2020, from https://talk.ictvonline.org/ictv-reports/ictv_online_report/negativesense-rna-viruses/w/rhabdoviridae 


\section{Appendix 1}

TABLE 1-A1: Non-volant small mammal species included in the surveillance of Mokola virus in South Africa.

\begin{tabular}{|c|c|c|c|c|c|}
\hline \multirow{2}{*}{$\begin{array}{l}\text { Non-volant } \\
\text { small mammal } \\
\text { type }\end{array}$} & \multirow{2}{*}{$\begin{array}{l}\text { Non-volant small } \\
\text { mammal species }\end{array}$} & \multicolumn{2}{|c|}{ Brain samples } & \multicolumn{2}{|c|}{ Serum samples } \\
\hline & & $\begin{array}{c}\text { Amount } \\
\text { tested }\end{array}$ & $\begin{array}{l}\text { Amount } \\
\text { positive }\end{array}$ & $\begin{array}{l}\text { Amount } \\
\text { tested }\end{array}$ & $\begin{array}{l}\text { Amount } \\
\text { positive }\end{array}$ \\
\hline \multicolumn{6}{|c|}{ Meletse, Limpopo, South Africa $(n=473)$} \\
\hline \multirow{3}{*}{$\begin{array}{l}\text { Shrews } \\
(n=9)\end{array}$} & Crocidura hirta & 2 & 0 & 2 & 0 \\
\hline & $\begin{array}{l}\text { Crocidura } \\
\text { maquassiensis }\end{array}$ & 1 & 0 & 1 & 0 \\
\hline & Suncus lixus & 3 & 0 & 0 & 0 \\
\hline Sengis $(n=8)$ & $\begin{array}{l}\text { Elephantulus } \\
\text { brachyrhynchus }\end{array}$ & 4 & 0 & 4 & 0 \\
\hline \multirow{17}{*}{$\begin{array}{l}\text { Rodents } \\
(n=457)\end{array}$} & Acomys selousi & 2 & 0 & 3 & 0 \\
\hline & Aethomys sp. & 1 & 0 & 16 & 0 \\
\hline & Aethomys ineptus & 30 & 0 & 23 & 0 \\
\hline & $\begin{array}{l}\text { Aethomys } \\
\text { chrysophilus }\end{array}$ & 20 & 0 & 16 & 0 \\
\hline & Gerbilliscus sp. & 1 & 0 & 5 & 5 \\
\hline & $\begin{array}{l}\text { Gerbilliscus } \\
\text { leucogaster }\end{array}$ & 33 & 0 & 36 & 31 \\
\hline & Graphiurus murinus & 3 & 0 & 2 & 0 \\
\hline & Lemniscomys rosalia & 9 & 0 & 7 & 0 \\
\hline & Mastomys coucha & 45 & 0 & 23 & 0 \\
\hline & $\begin{array}{l}\text { Mastomys natalensis } \\
\text { s.l. }\end{array}$ & 13 & 0 & 12 & 0 \\
\hline & Micaelamys sp. & 0 & 0 & 3 & 0 \\
\hline & $\begin{array}{l}\text { Micaelamys } \\
\text { namaquensis }\end{array}$ & 11 & 0 & 10 & 0 \\
\hline & $\begin{array}{l}\text { Mus (Nannomys) } \\
\text { minutoides }\end{array}$ & 29 & 0 & 12 & 0 \\
\hline & Rattus sp. & 2 & 0 & 0 & 0 \\
\hline & $\begin{array}{l}\text { Saccostomus } \\
\text { campestris }\end{array}$ & 19 & 0 & 19 & 0 \\
\hline & Steatomys sp. & 13 & 0 & 1 & 0 \\
\hline & Steatomys pratensis & 21 & 0 & 16 & 0 \\
\hline \multicolumn{2}{|c|}{$\begin{array}{l}\text { Total amount of samples tested for } \\
\text { Meletse }\end{array}$} & 262 & 0 & 211 & 36 \\
\hline
\end{tabular}

Secunda, Mpumalanga, South Africa $(n=102)$

$\begin{array}{llcccc}\text { Shrews } & \text { Crocidura sp. } & 2 & 0 & 0 & 0 \\ (n=3) & \text { Suncus sp. } & 1 & 0 & 0 & 0 \\ \text { Rodents } & \text { Mastomys sp. } & 40 & 0 & 26 & 0 \\ (n=101) & \text { Mastomys natalensis } & 3 & 0 & 3 & 0 \\ & \text { Rhabdomys sp. } & 21 & 0 & 6 & 0 \\ \\ \begin{array}{l}\text { Total amount of samples tested for } \\ \text { Secunda }\end{array} & 67 & 0 & 35 & 0\end{array}$

Note: Positive results are indicated in bold.

Sp., species.

TABLE 2-A1: Sampling event details of collected Gerbilliscus leucogaster serum samples from Meletse, Limpopo province and their seropositivity.

\begin{tabular}{|c|c|c|c|c|c|}
\hline Sampling (Month \& year) & Associated season $\dagger$ & $\begin{array}{l}\text { Number of serum } \\
\text { samples collected }\end{array}$ & $\begin{array}{l}\text { Number of serum samples } \\
\text { positive for MOKV VNAs }\end{array}$ & Percentage & Seropositivity \\
\hline February 2015 & Summer & 1 & 1 & 100.00 & $1 / 1$ \\
\hline January 2016 & Summer & 1 & 0 & 0.00 & $0 / 1$ \\
\hline September 2016 & Spring & 1 & 1 & 100.00 & $1 / 1$ \\
\hline November 2016 & Spring & 1 & 1 & 100.00 & $1 / 1$ \\
\hline March 2017 & Autumn/Fall & 17 & 15 & 88.24 & $15 / 17$ \\
\hline August 2017 & Winter & 3 & 3 & 100.00 & $3 / 3$ \\
\hline November 2017 & Spring & 7 & 7 & 100.00 & $100 / 100$ \\
\hline Total & & 41 & 36 & $87.80 \%$ & $36 / 41$ \\
\hline
\end{tabular}

MOKV VNAs, Mokola virus neutralising antibodies.

$\dagger$, Season delineation in South Africa: (1) Summer, 01 December to 28/29 February; (2) Autumn/Fall, 01 March to 31 May; (3) Winter, 01 June to 31 August; (4) Spring, 01 September to 30 November. 


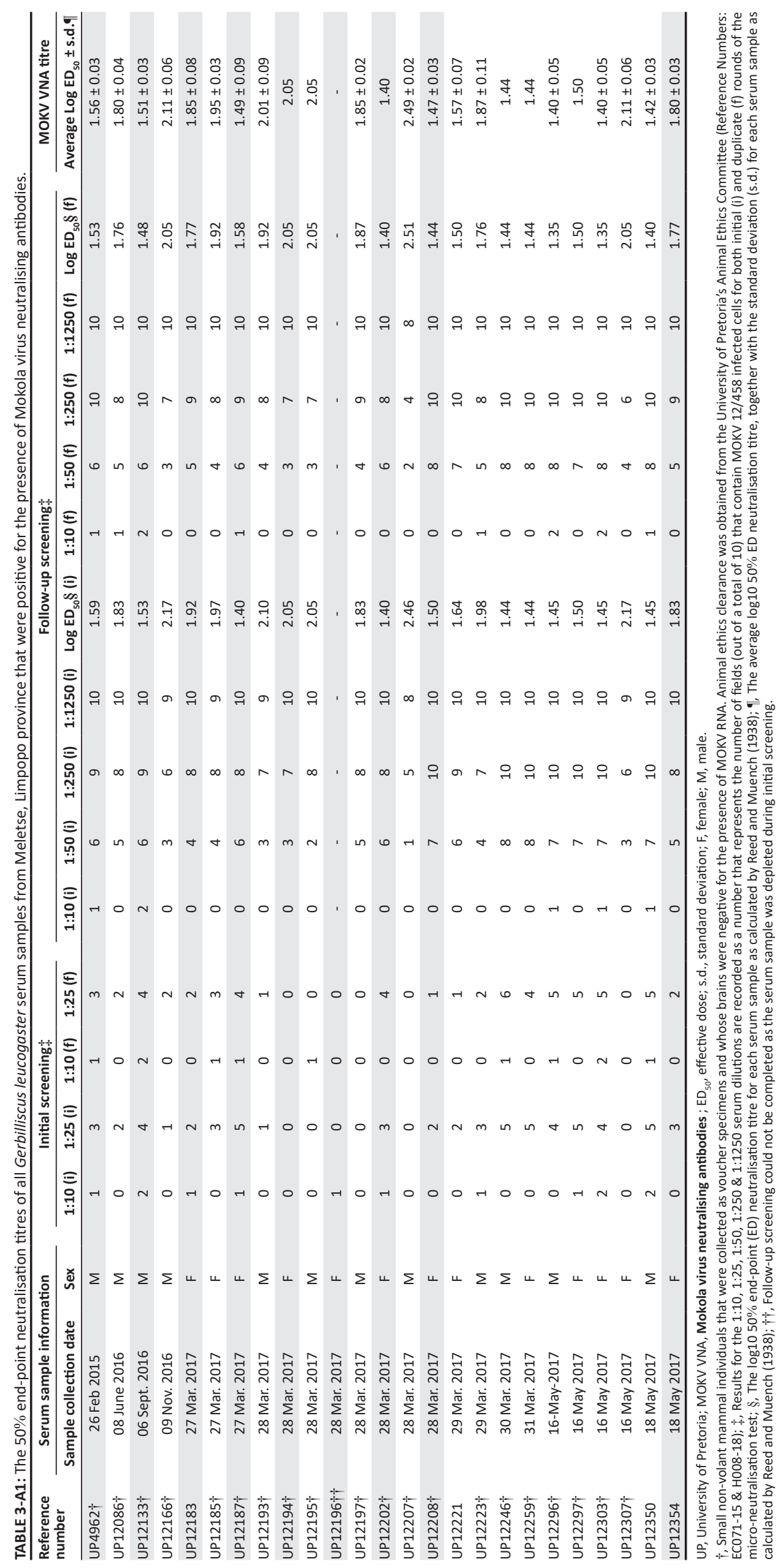


TABLE 4-A1: Micro-neutralisation test results of all non-volant small mammal serum samples that tested negative for the presence of Mokola virus neutralising antibodies. Reference Serum sample information

\begin{tabular}{|c|c|c|c|c|c|c|c|}
\hline \multirow{2}{*}{ number } & \multicolumn{3}{|c|}{ 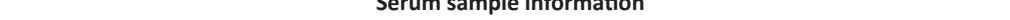 } & \multicolumn{4}{|c|}{ 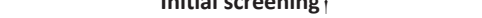 } \\
\hline & Sample collection date & Non-volant small mammal type & Non-volant small mammal species & $1: 10$ (i) & 1:25 (i) & $1: 10(f)$ & $1: 25$ (f) \\
\hline
\end{tabular}

\section{Meletse, Limpopo, South Africa $(n=211)$}

$4961 \quad 26$ Feb. 2015

496326 Feb. 2015

496727 Feb. 2015

$4968 \quad 27$ Feb. 2015

$4969 \quad 27$ Feb. 2015

501103 Mar. 2015

501203 Mar. 2015

501504 Mar. 2015

$5017 \quad 05$ Mar. 2015

$5352 \quad 12$ May 2015

$5353 \quad 12$ May 2015

$5354 \quad 12$ May 2015

$5355 \quad 12$ May 2015

$5356 \quad 12$ May 2015

$5525 \quad 22$ July 2015

$5527 \quad 23$ July 2015

$5528 \quad 24$ July 2015

$5529 \quad 24$ July 2015

$5934 \quad 15$ Sept. 2015

$5935 \quad 15$ Sept. 2015

593615 Sept. 2015

$5939 \quad 17$ Sept. 2015

$12001 \quad 10$ Nov. 2015

$12003 \quad 11$ Nov. 2015

$12004 \quad 11$ Nov. 2015

1200512 Nov. 2015

$12006 \quad 13$ Nov. 2015

$12007 \quad 13$ Nov. 2015

1201019 Jan. 2016

1201119 Jan. 2016

1201219 Jan. 2016

$12018 \quad 20$ Jan. 2016

1201920 Jan. 2016

$12020 \quad 20$ Jan. 2016

1202320 Jan. 2016

$12062 \quad 05$ Apr. 2016

$12065 \quad 06$ Apr. 2016

12066 06 Apr. 2016

$12067 \quad 06$ Apr. 2016

$12075 \quad 07$ June 2016

$12081 \quad 07$ June 2016

$12082 \quad 07$ June 2016

$12083 \quad 07$ June 2016

$12084 \quad$ 08 June 2016

$12085 \quad 08$ June 2016

$12087 \quad 08$ June 2016

$12088 \quad$ 09 June 2016

$12132 \quad 06$ Sept. 2016

$12134 \quad 06$ Sept. 2016

$12140 \quad 07$ Sept. 2016

$12142 \quad 07$ Sept. 2016

$12143 \quad 08$ Sept. 2016

12145 09 Sept. 2016

12146 09 Sept. 2016

12147 09 Sept. 2016

$12148 \quad 09$ Sept. 2016

$12149 \quad 09$ Sept. 2016

$12154 \quad 08$ Nov. 2016

12157

08 Nov. 2016

\section{Rodent}

Rodent

Rodent

Rodent

Rodent

Rodent

Rodent

Rodent

Rodent

Rodent

Sengi

Rodent

Sengi

Rodent

Rodent

Shrew

Rodent

Rodent

Rodent

Rodent

Rodent

Rodent

Rodent

Rodent

Rodent

Rodent

Rodent

Rodent

Rodent

Rodent

Rodent

Rodent

Rodent

Rodent

Rodent

Rodent

Rodent

Rodent

Rodent

Rodent

Rodent

Rodent

Rodent

Rodent

Rodent

Rodent

Rodent

Rodent

Rodent

Rodent

Sengi

Rodent

Rodent

Rodent

Rodent

Rodent

Rodent

Rodent
Aethomys chrysophilus

Aethomys chrysophilus

Aethomys chrysophilus

Saccostomus campestris

Aethomys chrysophilus

Steatomys pratensis

Aethomys chrysophilus

Steatomys pratensis

Steatomys pratensis

Aethomys ineptus

Elephantulus brachyrhynchus

Mastomys coucha

Elephantulus brachyrhynchus

Mastomys natalensis

Aethomys chrysophilus

Crocidura maquassiensis

Mastomys coucha

Mus (Nannomys) minutoides

Mus (Nannomys) minutoides

Micaelamys namaquensis

Aethomys ineptus

Mus (Nannomys) minutoides

Mastomys coucha

Aethomys chrysophilus

Steatomys pratensis

Aethomys ineptus

Aethomys ineptus

Steatomys pratensis

Mastomys coucha

Steatomys pratensis

Gerbilliscus leucogaster

Mastomys coucha

Saccostomus campestris

Mastomys coucha

Saccostomus campestris

Saccostomus campestris

Saccostomus campestris

Graphiurus murinus

Aethomys ineptus

Mastomys natalensis

Aethomys ineptus

Aethomys ineptus

Acomys selousi

Saccostomus campestris

Micaelamys namaquensis

Aethomys ineptus

Aethomys chrysophilus

Aethomys ineptus

Micaelamys sp.

Micaelamys sp.

Elephantulus brachyrhynchus

Micaelamys sp.

Micaelamys namaquensis

Acomys selousi

Steatomys pratensis

Saccostomus campestris

Saccostomus campestris

Micaelamys namaquensis

Aethomys chrysophilus

$\begin{array}{llll}10 & 10 & 9 & 10\end{array}$

10
7

10

10

\section{0}

10

10

10

10

7

9

8

10

10

10

\section{9}

10

8

10

10

10

\section{9}

9

9
10

9

10

10

10

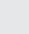

10
10

10
10

10
10

10

10
10

9

9

10


TABLE 4-A1 (Continues...): Micro-neutralisation test results of all non-volant small mammal serum samples that tested negative for the presence of Mokola virus neutralising antibodies.

\begin{tabular}{|c|c|c|c|c|c|c|c|}
\hline \multirow{2}{*}{$\begin{array}{l}\text { Reference } \\
\text { number }\end{array}$} & \multicolumn{3}{|c|}{ Serum sample information } & \multicolumn{4}{|c|}{ Initial screening $\dagger$} \\
\hline & Sample collection date & Non-volant small mammal type & Non-volant small mammal species & 1:10 (i) & $1: 25$ (i) & $1: 10(f)$ & $1: 25$ (f) \\
\hline 12159 & 09 Nov. 2016 & Rodent & Saccostomus campestris & 9 & 10 & 10 & 10 \\
\hline 12167 & 09 Nov. 2016 & Rodent & Aethomys chrysophilus & 9 & 9 & 10 & 10 \\
\hline 12168 & 10 Nov. 2016 & Rodent & Micaelamys namaquensis & 8 & 9 & 10 & 10 \\
\hline 12169 & 10 Nov. 2016 & Rodent & Mus (Nannomys) minutoides & 10 & 10 & 10 & 10 \\
\hline 12170 & 10 Nov. 2016 & Rodent & Aethomys chrysophilus & 8 & 10 & 7 & 10 \\
\hline 12171 & 11 Nov. 2016 & Rodent & Acomys spp. & 9 & 10 & 8 & 10 \\
\hline 12176 & 07 Feb. 2017 & Rodent & Saccostomus campestris & 3 & 9 & 3 & 10 \\
\hline 12177 & 08 Feb. 2017 & Rodent & Aethomys chrysophilus & 9 & 10 & 7 & 10 \\
\hline 12178 & 08 Feb. 2017 & Rodent & Aethomys ineptus & 6 & 9 & 7 & 9 \\
\hline 12179 & 08 Feb. 2017 & Rodent & Aethomys ineptus & 6 & 9 & 7 & 9 \\
\hline 12180 & 09 Feb. 2017 & Rodent & Aethomys chrysophilus & 10 & 10 & 9 & 10 \\
\hline 12181 & 09 Feb. 2017 & Rodent & Aethomys chrysophilus & 10 & 10 & 10 & 10 \\
\hline 12184 & 27 Mar. 2017 & Rodent & Gerbilliscus leucogaster & 3 & 6 & 2 & 6 \\
\hline 12189 & 27 Mar. 2017 & Rodent & Saccostomus campestris & 7 & 10 & 6 & 9 \\
\hline 12190 & 27 Mar. 2017 & Rodent & Steatomys pratensis & 10 & 10 & 10 & 10 \\
\hline 12191 & 27 Mar. 2017 & Rodent & Steatomys pratensis & 10 & 10 & 10 & 10 \\
\hline 12192 & 28 Mar. 2017 & Rodent & Steatomys pratensis & 10 & 10 & 9 & 10 \\
\hline 12200 & 28 Mar. 2017 & Rodent & Gerbilliscus leucogaster & 4 & 7 & 5 & 7 \\
\hline 12201 & 28 Mar. 2017 & Rodent & Steatomys pratensis & 10 & 10 & 9 & 10 \\
\hline 12203 & 28 Mar. 2017 & Rodent & Mastomys coucha & 6 & 9 & 6 & 10 \\
\hline 12204 & 28 Mar. 2017 & Rodent & Aethomys ineptus & 7 & 10 & 8 & 10 \\
\hline 12205 & 28 Mar. 2017 & Rodent & Mastomys coucha & 9 & 10 & 10 & 10 \\
\hline 12206 & 28 Mar. 2017 & Rodent & Mastomys coucha & 5 & 9 & 8 & 9 \\
\hline 12209 & 29 Mar. 2017 & Rodent & Aethomys chrysophilus & 8 & 10 & 7 & 10 \\
\hline 12210 & 29 Mar. 2017 & Rodent & Mastomys coucha & 10 & 10 & 10 & 10 \\
\hline 12211 & 29 Mar. 2017 & Rodent & Steatomys pratensis & 9 & 10 & 8 & 10 \\
\hline 12212 & 29 Mar. 2017 & Rodent & Aethomys chrysophilus & 8 & 10 & 9 & 10 \\
\hline 12216 & 29 Mar. 2017 & Rodent & Steatomys pratensis & 10 & 10 & 10 & 10 \\
\hline 12217 & 29 Mar. 2017 & Rodent & Mastomys coucha & 8 & 10 & 7 & 10 \\
\hline 12218 & 29 Mar. 2017 & Rodent & Saccostomus campestris & 8 & 9 & 10 & 10 \\
\hline 12219 & 29 Mar. 2017 & Rodent & Steatomys pratensis & 8 & 10 & 8 & 10 \\
\hline 12236 & 30 Mar. 2017 & Rodent & Saccostomus campestris & 9 & 10 & 8 & 10 \\
\hline 12237 & 30 Mar. 2017 & Rodent & Mus (Nannomys) minutoides & 9 & 10 & 9 & 10 \\
\hline 12238 & 30 Mar. 2017 & Rodent & Mastomys coucha & 7 & 10 & 6 & 10 \\
\hline 12240 & 30 Mar. 2017 & Rodent & Saccostomus campestris & 10 & 10 & 10 & 10 \\
\hline 12242 & 30 Mar. 2017 & Rodent & Aethomys ineptus & 9 & 10 & 7 & 10 \\
\hline 12244 & 30 Mar. 2017 & Rodent & Saccostomus campestris & 10 & 10 & 10 & 10 \\
\hline 12248 & 30 Mar. 2017 & Rodent & Saccostomus campestris & 10 & 10 & 10 & 10 \\
\hline 12256 & 31 Mar. 2017 & Rodent & Graphiurus murinus & 8 & 10 & 10 & 10 \\
\hline 12258 & 31 Mar. 2017 & Rodent & Steatomys pratensis & 10 & 10 & 10 & 10 \\
\hline 12260 & 31 Mar. 2017 & Rodent & Steatomys pratensis & 10 & 10 & 10 & 10 \\
\hline 12285 & 16 May 2017 & Rodent & Micaelamys namaquensis & 8 & 9 & 9 & 10 \\
\hline 12289 & 16 May 2017 & Rodent & Saccostomus campestris & 10 & 10 & 10 & 10 \\
\hline 12291 & 16 May 2017 & Rodent & Micaelamys namaquensis & 9 & 10 & 10 & 10 \\
\hline 12292 & 16 May 2017 & Rodent & Aethomys ineptus & 9 & 10 & 10 & 10 \\
\hline 12294 & 16 May 2017 & Rodent & Aethomys ineptus & 8 & 10 & 8 & 10 \\
\hline 12295 & 16 May 2017 & Rodent & Aethomys ineptus & 10 & 10 & 10 & 10 \\
\hline 12298 & 16 May 2017 & Rodent & Mastomys coucha & 10 & 10 & 10 & 10 \\
\hline 12299 & 16 May 2017 & Rodent & Mus (Nannomys) minutoides & 10 & 10 & 10 & 10 \\
\hline 12300 & 16 May 2017 & Rodent & Mastomys coucha & 9 & 10 & 10 & 10 \\
\hline 12301 & 16 May 2017 & Rodent & Mastomys coucha & 10 & 10 & 10 & 10 \\
\hline 12302 & 16 May 2017 & Rodent & Aethomys sp. & 10 & 10 & 10 & 10 \\
\hline 12304 & 16 May 2017 & Rodent & Aethomys sp. & 10 & 10 & 10 & 10 \\
\hline 12305 & 16 May 2017 & Rodent & Lemniscomys rosalia & 9 & 10 & 10 & 10 \\
\hline 12306 & 16 May 2017 & Rodent & Mastomys coucha & 9 & 10 & 10 & 10 \\
\hline
\end{tabular}


TABLE 4-A1 (Continues...): Micro-neutralisation test results of all non-volant small mammal serum samples that tested negative for the presence of Mokola virus neutralising antibodies.

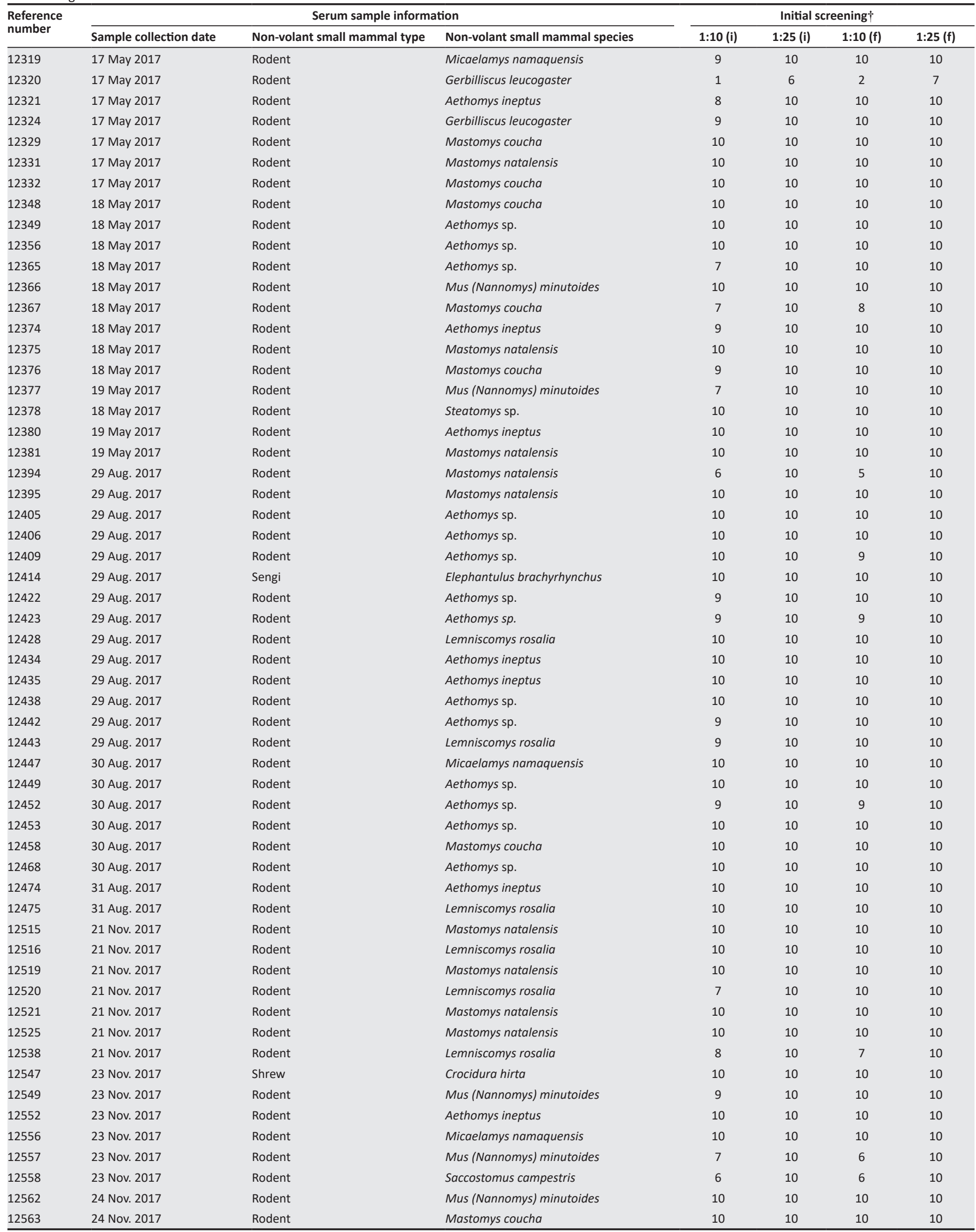


TABLE 4-A1 (Continues...): Micro-neutralisation test results of all non-volant small mammal serum samples that tested negative for the presence of Mokola virus neutralising antibodies.

\begin{tabular}{|c|c|c|c|c|c|c|c|}
\hline \multirow{2}{*}{$\begin{array}{l}\text { Reference } \\
\text { number }\end{array}$} & \multicolumn{3}{|c|}{ Serum sample information } & \multicolumn{4}{|c|}{ Initial screening $\dagger$} \\
\hline & Sample collection date & Non-volant small mammal type & Non-volant small mammal species & $1: 10$ (i) & $1: 25$ (i) & $1: 10(f)$ & $1: 25$ (f) \\
\hline \multicolumn{8}{|c|}{ Secunda, Mpumalanga, South Africa $(n=35)$} \\
\hline 5532 & 30 June 2015 & Rodent & Mastomys sp. & 9 & 9 & 9 & 10 \\
\hline 5552 & 01 July 2015 & Rodent & Mastomys sp. & 10 & 10 & 10 & 10 \\
\hline 5553 & 01 July 2015 & Rodent & Mastomys sp. & 4 & 6 & 5 & 6 \\
\hline 5566 & 02 July 2015 & Rodent & Mastomys sp. & 9 & 10 & 10 & 9 \\
\hline 5567 & 02 July 2015 & Rodent & Mastomys sp. & 9 & 10 & 10 & 10 \\
\hline 5568 & 02 July 2015 & Rodent & Rhabdomys sp. & 10 & 10 & 10 & 10 \\
\hline 5569 & 02 July 2015 & Rodent & Rhabdomys sp. & 10 & 10 & 10 & 10 \\
\hline 5570 & 03 July 2015 & Rodent & Mastomys sp. & 10 & 10 & 10 & 9 \\
\hline 5571 & 03 July 2015 & Rodent & Mastomys sp. & 10 & 9 & 10 & 10 \\
\hline 5572 & 03 July 2015 & Rodent & Rhabdomys sp. & 10 & 10 & 10 & 10 \\
\hline 5573 & 03 July 2015 & Rodent & Mastomys sp. & 10 & 10 & 10 & 10 \\
\hline 5574 & 03 July 2015 & Rodent & Mastomys sp. & 10 & 10 & 10 & 10 \\
\hline 5575 & 03 July 2015 & Rodent & Rhabdomys sp. & 9 & 10 & 10 & 9 \\
\hline 5576 & 03 July 2015 & Rodent & Rhabdomys sp. & 9 & 10 & 10 & 10 \\
\hline 5577 & 03 July 2015 & Rodent & Mastomys sp. & 9 & 10 & 10 & 10 \\
\hline 5580 & 03 July 2015 & Rodent & Mastomys sp. & 10 & 10 & 10 & 10 \\
\hline 5581 & 03 July 2015 & Rodent & Mastomys sp. & 9 & 10 & 9 & 9 \\
\hline 5582 & 03 July 2015 & Rodent & Mastomys sp. & 10 & 10 & 9 & 10 \\
\hline 5584 & 03 July 2015 & Rodent & Mastomys sp. & 10 & 10 & 10 & 10 \\
\hline 5585 & 03 July 2015 & Rodent & Mastomys sp. & 9 & 9 & 10 & 9 \\
\hline 5586 & 03 July 2015 & Rodent & Mastomys sp. & 9 & 10 & 10 & 10 \\
\hline 12025 & 26 Jan. 2016 & Rodent & Mastomys natalensis & 9 & 10 & 9 & 10 \\
\hline 12026 & 26 Jan. 2016 & Rodent & Mastomys natalensis & 10 & 10 & 10 & 10 \\
\hline 12027 & 26 Jan. 2016 & Rodent & Mastomys natalensis & 10 & 10 & 10 & 10 \\
\hline 12028 & 27 Jan. 2016 & Rodent & Mastomys sp. & 9 & 10 & 8 & 10 \\
\hline 12029 & 27 Jan. 2016 & Rodent & Mastomys sp. & 10 & 10 & 10 & 10 \\
\hline 12030 & 27 Jan. 2016 & Rodent & Mastomys sp. & 10 & 10 & 10 & 10 \\
\hline 12031 & 27 Jan. 2016 & Rodent & Rhabdomys sp. & 10 & 10 & 10 & 10 \\
\hline 12032 & 27 Jan. 2016 & Rodent & Mastomys sp. & 5 & 8 & 5 & 7 \\
\hline 12034 & 27 Jan. 2016 & Rodent & Mastomys sp. & 10 & 10 & 10 & 10 \\
\hline 12035 & 28 Jan. 2016 & Rodent & Mastomys sp. & 8 & 10 & 3 & 10 \\
\hline 12036 & 28 Jan. 2016 & Rodent & Mastomys sp. & 10 & 10 & 10 & 10 \\
\hline 12037 & 28 Jan. 2016 & Rodent & Mastomys sp. & 10 & 10 & 10 & 10 \\
\hline 12038 & 28 Jan. 2016 & Rodent & Mastomys sp. & 9 & 10 & 10 & 10 \\
\hline 12050 & 29 Jan. 2016 & Rodent & Mastomys sp. & 10 & 10 & 10 & 10 \\
\hline
\end{tabular}

Sp., species.

$\dagger$, Results for the 1:10 and 1:25 serum dilutions are recorded as a number that represents the number of fields (out of a total of 10) that contain MOKV $12 / 458$ infected cells for both initial (i) and duplicate (f) rounds of the micro-neutralisation test. 


\section{Appendix 2}

\section{Additional References}

Bingham, J., Javangwe, S., Sabeta, C.T., Wandeler, A.I. \& Nel, L.H., 2001, 'Report of isolations of unusual lyssaviruses (rabies and Mokola virus) identified retrospectively from Zimbabwe', Journal of the South African Veterinary Association 72(2), 92-94. https://doi.org/10.4102/jsava.

Causey, O.R. \& Kemp, G.E., 1968, 'Surveillance and study of viral infections of vertebrates in Nigeria', Nigerian Journal of Science 2, 131-135.

Familusi, J.B. \& Moore, D.L., 1972, 'Isolation of a rabies-related virus from the cerebrospinal fluid of a child with "aseptic meningitis"', African Journal of Medical Sciences 3(1), 93-96.

Foggin, C.M., 1982, 'Atypical rabies virus in cats and a dog in Zimbabwe', Veterinary Record 110(14), 338-338. https://doi.org/10.1136/vr.110.14.338

Foggin, C.M., 1983, 'Mokola virus infection in cats and a dog in Zimbabwe', The Veterinary Record 113(5), 115. https://doi.org/10.1136/vr.113.5.115
Mebatsion, T., Cox, J.H. \& Frost, J.W., 1992, 'Isolation and characterization of 115 street rabies virus isolates from Ethiopia by using monoclonal antibodies: Identification of 2 isolates as Mokola and Lagos bat viruses', Journal of Infectious Diseases 166(5), 972-977. https://doi.org/10.1093/infdis/166.5.972

Meredith, C.D. \& Nel, L.H., 1996, 'Further isolation of Mokola virus in South Africa', The Veterinary Record 138(5), 119-120.

Nel, L., Jacobs, J., Jaftha, J., Von Teichman, B. \& Bingham, J., 2000, 'New cases of Mokola virus infection in South Africa: A genotypic comparison of Southern African virus isolates', Virus Genes 20(2), 103-106. https://doi.org/10.1023/A:1008120511752

Sabeta, C.T., Blumberg, L., Miyen, J., Mohale, D., Shumba, W. \& Wandeler, A., 2010, 'Mokola virus involved in a human contact (South Africa)', FEMS Immunology \& Medical Microbiology 58(1), 85-90. https://doi.org/10.1111/j.1574-695X.2009.00609.x

Sabeta, C.T., Markotter, W., Mohale, D.K., Shumba, W., Wandeler, A.I. \& Nel, L.H., 2007, 'Mokola virus in domestic mammals, South Africa', Emerging Infectious Diseases 13(9), 1371. https://doi.org/10.3201/eid1309.070466

Von Teichman, B.F., De Koker, W.C., Bosch, S.J.E., Bishop, G.C., Meredith, C.D. \& Bingham, J., 1998, 'Mokola virus infection: Description of recent South African cases and a review of the virus epidemiology: Case report', Journal of the South African Veterinary Association 69(4), 169-171. https://doi.org/10.4102/jsava v69i4.847 